Vol. 1 No. 3 Juli 2021 e-ISSN : 2774-6283 | p-ISSN : 2775-0019

\title{
MENINGKATKAN HASIL BELAJAR MATEMATIKA MELALUI METODE PROBLEM BASED INSTRUCTION DI KELAS X SMK NEGERI 1 TANJUNG PALAS TAHUN 2017/2018
}

\author{
SANDIATI TOMBANG \\ SMK Negeri 1 Tanjung Palas Kalimantan Utara \\ e-mail: arkinpasangallo@yahoo.com
}

\begin{abstract}
ABSTRAK
Tujuan dari penelitian ini adalah untuk meningkatkan hasil belajar peserta didik melalui metode Problem Based Instuction pada materi perbandingan trigonometri pada segitiga siku-siku kelas X Multimedia SMK Negeri 1 Tanjung Palas Tahun Pelajaran 2017/2018. Penelitian ini merupakan penelitian tindakan kelas yang dilakukan dalam 2 siklus yang masing-masing terdiri dari 4 tahap yaitu perencanaan, pelaksanaan tindakan, observasi, dan refleksi. Hasil tes hasil belajar peserta didik menunjukkan bahwa pada kondisi awal diperoleh nilai rata-rata mencapai 66,66. Pada siklus I nilai tes rata-rata mencapai 77,22 dan pada tes hasil belajar peserta didik di tahap II diperoleh nilai rata-rata sebesar 82,5. Hal ini berarti bahwa ada peningkatan hasil belajar peserta didik dari kondisi awal sampai siklus II sebesar 15,84. Jadi dapat disimpulkan bahwa dengan menggunakan metode Problem Based Instruction dapat meningkatkan hasil belajar Matematika di kelas X SMK Negeri 1 Tanjung Palas.
\end{abstract}

Kata Kunci: Hasil Belajar Matematika, Metode Problem Based Introduction,

\section{PENDAHULUAN}

Penilaian pada dasarnya bertujuan untuk mengetahui perkembangan hasil belajar peserta didik dan hasil mengajar guru. Informasi hasil belajar berupa kompetensi dasar yang sudah dipahami dan belum dipahami oleh sebagian besar peserta didik. Hasil belajar peserta didik digunakan untuk memotivasi peserta didik dan guru agar melakukan perbaikan dan peningkatan kualitas proses pembelajaran. Hasil belajar pada hakikatnya merupakan perubahan tingkah laku sebagai hasil belajar dalam pengetahuan yang luas mencakup bidang kognitif, afektif, dan psikomotorik (Sudjana:2009). Beberapa faktor yang menunjukkan rendahnya tingkat kemampuan pemecahan masalah adalah hasil nilai ulangan masih rendah. Selain itu, kemampuan peserta didik dalam menyelesaikan soal yang berkaitan dengan materi Trigonometri masih kurang, banyak peserta didik yang mengalami kesulitan untuk memahami maksud soal, merumuskan apa yang diketahui, bahkan proses perhitungan atau strategi penyelesaian masih tidak benar.

Faktor-faktor yang menyebabkan timbulnya masalah-masalah dalam pembelajaran Matematika, antara lain; proses pembelajaran belum efektif, suasana belajar mengajar yang kurang kondusif, tingkat keaktifan peserta didik masih kurang, metode pembelajaran yang digunakan guru belum mampu mengaktifkan peserta didik dalam belajar, proses pembelajaran lebih terpusat pada guru yaitu proses pembelajaran didominasi guru, dan peserta didik mengerjakan soal-soal latihan. Indikator tersebut akan menjadi instrumen untuk lembar pengamatan bagi guru ketika proses berlangsung yaitu apakah model yang diterapkan sudah menyebabkan siswa (1) aktif, (2) bermotivasi tinggi, (3) suasananya menyenangkan, dan (4) hasilnya baik (Arikunto, 2015). Kebiasaan belajar peserta didik yang hanya terbiasa belajar dengan cara menghafal menjadi salah satu faktor kurangnya kemampuan pemecahan masalah matematis pada peserta didik. Cara ini merupakan akibat dari pembelajaran konvensional dimana guru mengajar dengan metode ceramah dan memberikan contoh mengerjakan soal, serta meminta peserta didik untuk mengerjakan soal sejenis dengan soal yang telah diterangkan oleh guru.

Demikian halnya juga kegiatan pembelajaran Matematika di SMK Negeri 1 Tanjung Palas, masih banyak kendala yang dialami dalam melaksanakan kegiatan pembelajaran yang mengakibatkan rendahnya nilai hasil belajar peserta didik. Hal ini bisa terlihat dari data yang 
telah peneliti ambil sebagai sampel dalam penelitian tindakan kelas yaitu dari 31 orang peserta didik kelas X SMK Negeri 1 Tanjung Palas Tahun Pelajaran 2017/2018, hanya ada 11 orang yang dinyatakan memenuhi kriteria ketuntasan minimal (KKM). Hasil observasi berupa antusiasme peserta didik dalam mengikuti pelajaran, kemampuan peserta didik dalam mengungkapkan pendapat, kemampuan peserta didik untuk bertanya, dan kemampuan peserta didik dalam bekerjasama menunjukkan skor 59, artinya aktifitas peserta didik didalam proses pembelajaran masih relatif rendah, yang mengakibatkan rendahnya pemahaman peserta didik akan materi yang diajarkan yang berefek kepada hasil belajar peserta didik tersebut.

Bertolak dari permasalah tersebut, peneliti merasa perlu meningkatkan strategi atau metode pembelajaran yang lebih menarik sehingga dapat menciptakan suasana lingkungan belajar yang aktif, kreatif, efektif, dan menyenangkan bagi peserta didik. Untuk itu peneliti mencoba menggunakan metode Problem Based Instruction dalam meningkatkan hasil belajar peserta didik. Kemampuan seseorang untuk dapat berhasil dalam kehidupannya antara lain ditentukan oleh kemampuan berpikirnya, terutama dalam memecahkan masalah-masalah kehidupan yang dihadapinya (Ibrahim, 2007). Metode Problem Based Instruction adalah metode mengajar yang menggunakan peragaan untuk memperjelas suatu pengertian atau untuk memperlihatkan pada seluruh kelas tentang suatu proses atau suatu petunjuk untuk melakukan sesuatu. Pembelajaran ini bertujuan untuk membantu peserta didik mengembangkan kemampuan berpikir peserta didik (Ibrahim, 2005). Menurut Kurniasih (2015), model pembelajaran PBI bertujuan untuk menggali kreativitas peserta didik dalam berpikir dan memotivasi peserta didik untuk terus belajar. Sedangkan menurut Nurhadi (2004) menyatakan bahwa Problem Based Instruction meruapakan model pembelajaran yang menggunakan masalah dunia nyata sebagai suatu konteks untuk belajar tentang cara berpikir kritis dan keterampilan pemecahan masalah, serta memperoleh pengetahuan dan konsep yang essensial dari mata pelajaran.

Penelitian ini secara umum bertujuan untuk mengkaji dan mendeskripsikan penerapan model Problem Based Instruction dalam meningkatkan hasil belajar Matematika pada pokok bahasan Trigonometri pada Segitiga Siku-siku kelas X SMK Negeri 1 Tanjung Palas. Melalui metode Problem Based Instruction ini, peserta didik diharapkan dapat mengaitkan permasalahan dengan kehidupan sehari-hari.

\section{METODE PENELITIAN}

Jenis penelitian yang digunakan oleh guru dalam memperbaiki mutu pembelajaran adalah Penelitian Tindakan Kelas (Classroom Action Research). Desain penelitian yang dilakukan mengacu pada desain penelitian Kemmis dan Mc. Taggart yang terdiri dari empat komponen, yaitu (1) perencanaan, pembelajaran yang akan dilakukan harus terlebih dahulu dirancang oleh guru, dan guru hanya bertugas sebagai fasilitator dan pembimbing (Darsono, 2000). Guru menyusun RPP dengan menggunakan metode Problem Based Instruction , pada setiap pertemuan disiapkan lembar kerja peserta didik (LKPD) dan soal tes, untuk mengambil data tentang aktifitas guru dan peserta didik, peneliti menyiapkan lembar observasi guru dan peserta didik, (2) tindakan, pada saat pelaksanaan tindakan, guru melaksanakan proses pembelajaran mulai dari pembukaan dan sampai kegiatan akhir sesuai dengan RPP yang telah disusun sebelumnya, (3) pengamatan, pada pelaksanaan pengamatan aktifitas peserta didik, guru menggunakan lembar observasi yang meliputi beberapa aspek sasaran observasi seperti kemampuan peserta didik dalam mendengarkan materi yang disampaikan oleh guru, antusias peserta didik dalam mengikuti pelajaran, kemampuan peserta didik dalam mengungkapkan pendapatnya, kemampuan peserta didik dalam bertanya, dan kemampuan peserta didik dalam bekerjasama secara kelompok, dan (4) refleksi, melakukan refleksi tentang hasil aktivitas belajar peserta didik selama proses pembelajaran untuk menyimpulkan bahwa dengan menggunakan metode Problem Based Instruction, maka hasil belajar peserta didik mengalami peningkatan ( Aries dan Haryono, 2012). Subjek penelitian ini adalah peserta didik Kelas X 
Multimedia yang terdaftar pada tahun ajaran 2017/2018 dengan jumlah peserta didik 31 orang, yang terdiri dari 14 orang laki-laki dan 17 orang perempuan.

Penelitian Tindakan Kelas ini dilakukan dengan 3 siklus yakni (1) pra siklus, (2) siklus I, dan (3) siklus II. Pada kondisi prasiklus peneliti belum melaksanakan metode Problem Based Instruction, namun peneliti mengamati aktifitas belajar peserta didik dan melakukan test tentang perbandingan trigonometri pada segitiga siku-siku untuk mengetahui hasil belajar peserta didik sebelum peneliti menggunakan metode Problem Based Instruction. Teknik pengumpulan data yang digunakan dalam penelitian ini berupa (1) observasi yang digunakan untuk mengamati pelaksanaan dan perkembangan pembelajaran materi yang dilakukan oleh guru dan siswa, pengamatan dilakukan sebelum, selama dan sesudah siklus penelitian berlangsung, (2) tes yang digunakan untuk mengetahui perkembangan atau keberhasilan pelaksanaan tindakan, adapun bentuk tes yang diberikan kepada siswa yakni tes tertulis bentuk pilihan ganda.

\section{HASIL DAN PEMBAHASAN}

\section{Hasil Penelitian}

Sebelum melakukan tindakan dengan menggunakan metode Problem Based Instruction, peneliti melaksanakan tes awal untuk mengetahui tingkat pemahaman peserta didik tentang materi perbandingan trigonometri pada segitiga siku-siku, pada hari tanggal 30 Oktober 2017, dan peserta didik yang memenuhi Kriteria Ketuntasan Minimal (KKM) mencapai 11 orang, dengan nilai rata-rata mencapai 66,66. Siklus I dilaksanakan pada tanggal 06 dan 07 November 2017, dan jumlah peserta didik yang memenuhi Kriteria Ketuntasan Minimal (KKM) mencapai 23 orang dengan nilai rata-rata mencapai 77,22. Siklus II dilaksanakan pada tanggal 20 dan 21 November 2017 dan jumlah peserta didik yang memenuhi Kriteria Ketuntasan Belajar Tuntas Minimal (KKM) mencapai 31 orang, dengan nilai rata-rata mencapai 82,5. Data tersebut dapat diperlihatkan dalam bentuk grafik berikut:

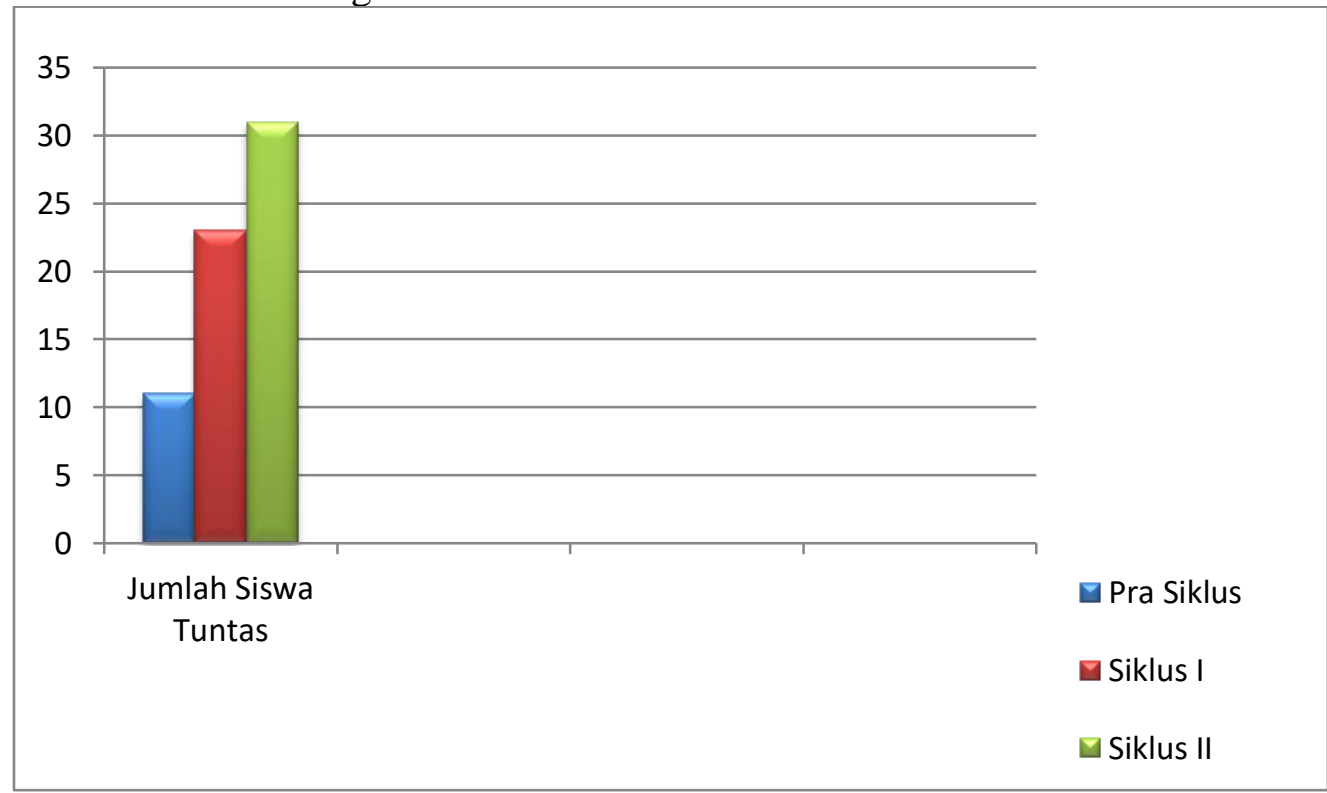

Gambar 1. Grafik Peningkatan Hasil Belajar Peserta Didik

Tabel 1. Distribusi Hasil Belajar Peserta Didik

\begin{tabular}{|c|l|c|c|c|c|}
\hline No. & $\begin{array}{c}\text { Hasil } \\
\text { Siklus }\end{array}$ & $\begin{array}{c}\text { Jumlah Peserta } \\
\text { Didik yang } \\
\text { Memenuhi KKM }\end{array}$ & $\begin{array}{c}\text { Jumlah Peserta } \\
\text { Didik yang Tidak } \\
\text { Memenuhi KKM }\end{array}$ & $\begin{array}{c}\text { Skor } \\
\text { Keaktifan } \\
\text { Peserta } \\
\text { Didik }\end{array}$ & Persentase \\
\hline 1 & Prasiklus & 11 & 20 & 59 & 66,66 \\
\hline 2 & Siklus I & 23 & 8 & 108 & 77,22 \\
\hline 3 & Siklus II & 31 & 0 & 139 & 82,50 \\
\hline
\end{tabular}




\section{Pembahasan}

Penelitian ini dilaksanakan pada peserta didik kelas X Multimedia SMK Negeri 1 Tanjung Palas dengan menggunakan metode pembelajaran Problem Based Instruction, dimana peserta didik tidak hanya dituntut untuk mendengarkan penjelasan guru, melainkan peserta didik juga berperan aktif dalm proses pembelajaran. Model pembelajaran Problem Based Instruction merupakan pembelajaran yang menuntut peserta didik untuk mejadi mandiri dalam memecahkan masalah. Pembelajaran Problem Based Instruction juga dapat menjadi alat untuk mengubah karakter dan pola pikir peserta didik dalam memecahkan masalah baik secara individu maupun secara berkelompok.

Prasiklus merupakan tahap pembelajaran yang diterapkan sebelum metode problem based instruction diiterapkan pada peserta didik untuk materi perbandingan trigonometri pada segitiga siku-siku. Berdasarkan data hasil penelitian pada Gambar 1, peserta didik pada tahap prasiklus yang memenuhi Kriteria Ketuntasan Minimal (KKM) berjumlah 11 orang, dengan nilai rata-rata mencapai 66,66. Hasil observasi menunjukkan skor 59, artinya aktifitas peserta didik didalam kelas kurang antusias dan pasif dalam mengikuti pelajaran, dan juga masih belum percaya diri dalam mengungkapkan pendapatnya, dan belum mampu untuk bekerjasama dalam kelompok. Menurut Purwatiningsih (2013), pemberian tes awal bertujuan untuk mengetahui pengetahuan peserta didik tentang materi prasyarat. Nilai tersebut digunakan sebagai nilai awal untuk membandingkan dan sekaligus memperbaiki hasil belajar peserta didik pada tahap berikutnya, dimana akan diterapkan metode problem based instruction pada tahap I dan tahap II sehingga hasilnya dapat mencapai kriteria ketuntasan minimal yang diharapkan.

Pada siklus I jumlah peserta didik yang memenuhi kriteria ketuntasan minimal mengalami peningkatan yakni mencapai 23 orang, nilai rata-rata mencapai 77,22. Artinya metode problem based instruction efektif digunakan untuk meningkatkan hasil belajar peserta didik pada materi perbandingan trigonometri pada segitiga siku-siku. Pada kegiatan observasi peserta didik, guru menilai bahwa peserta didik mendengarkan materi yang di sampaikan guru, peserta didik terlihat antusias dalam mengikuti pembelajaran Matematika materi perbandingan trigonometri pada segitiga siku-siku, meningkatnya rasa percaya diri peserta didik dalam mengungkapkan pendapatnya, peserta didik juga sudah mulai aktif bertanya tentang hal-hal yang tidak di ketahui dan peserta didik juga sudah mulai bisa berkomunikasi dalam kelompok dengan teman lainnya. Hasil observasi menunjukkan skor 108. Artinya aktifitas peserta didik di dalam kelas megalami peningkatan. Akan tetapi agar lebih kondusif lagi pembelajaran Matematika materi perbandingan trigonometri pada segitiga siku-siku maka peneliti hendak melaksanakan siklus II.

Pada siklus II jumlah peserta didik yang memenuhi kriteria ketuntasan minimal mengalami peningkatan dari tahap siklus II yaitu mencapai 31 orang, nilai rata-rata mencapai 82,5. Artinya metode problem based introduction efektif di gunakan untuk meningkatkan hasil belajar peserta didik pada materi Perbandingan trigonometri pada segitiga siku-siku.. Hasil observasi menunjukkan skor 139 Artinya aktifitas peserta didik didalam kelas sangat baik. Dimana peserta didik sudah mampu dalam mengikuti diskusi dengan baik, mampu melakukan tanya jawab untuk mendapat kesepakatan bersama, sudah mampu terjadi interaksi antar anggota kelompok, mampu bertanggung jawab dengan tugas yang diterima, mampu menyampaikan pendapat dengan komunikasi yang baik dan jelas, dan mampu dalam melakukan diskusi kembali untuk memperkuat hasil jawaban dan mencocokkan hasil disksusi.

Hasil penelitian menunjukkan bahwa terdapat pengaruh Metode Problem Based Instruction terhadap hasil belajar Matematika pada peserta didik kelas X Multimedia SMKN 1 Tanjung Palas. Hal ini dapat dilihat dari nilai rata-rata kelas eksperimen yang diajar dengan metode Problem Based Instruction lebih tinggi daripada nilai rata-rata yang diajar tanpa menggunakan metode Problem Based Instruction. Hal ini diperkuat dengan banyakanya penelitian-penelitian yang serupa diantaranya hasil penelitian Ramadhani (2013) yang mengatakan bahwa "siswa yang diajar dengan model pembelajaran PBI memperoleh hasil 
belajar Matematika yang lebih tinggi dari siswa yang diajar dengan model pembelajaran konvensional"

\section{KESIMPULAN}

Sesuai dengan hasil penelitian dan pembahasan, dapat disimpulkan bahwa setelah diterapkan tindakan pembelajaran Matematika dengan menggunakan Metode Problem Based Instruction (PBI), terjadi peningkatan hasil belajar Matematika pada peserta didik kelas X SMK Negeri 1 Tanjung Palas T.A 2017/2018. Peningkatan ini terlihat dari dari hasil observasi dan post test yang dilakukan mulai dari tahapan prasiklus, tahap siklus I, dan tahapan siklus II. Data peningkatan hasil belajar peserta didik dapat dilihat dari rata-rata perolehan nilai peserta didik pada masing-masing siklus mengalami peningkatan yakni pada prasiklus rata-rata hasil belajar 66,66; rata-rata hasil belajar mencapai 77,22 pada siklus 1; dan rata-rata hasil belajar mencapai 82,50 pada tahapan siklus II . Dari hasil observasi dalam proses pembelajaran, perilaku peserta didik ketika guru menerapkan metode Problem Based Instruction mengalami perubahan kearah yang positif dimana peserta didik lebih aktif dan lebih percaya diri dalam kegiatan pembelajaran.

\section{DAFTAR PUSTAKA}

Aries, Erna Febru dan Ari Dwi Haryono. (2012). Penelitian Tindakan Kelas. Yogyakarta: Aditya Media Publishing.

Arikunto, Suharsimi.(2015). Penelitian Tindakan Kelas. Jakarta: PT. Bumi Aksara.

Darsono, Max. (2000). Belajar dan Pembelajaran. Semarang: IKIP Semarang.

Ibrahim, Muslimin. (2005). Pembelajaran Berdasarkan Masalah. Surabaya: UNESA University Press.

Ibrahim, M. (2007). Kecakapan Hidup: Keterampilan Berpikir Kritis. Surabaya: Universitas Negeri Surabaya.

Kurniasih, Imas (2015). Ragam Pengembangan Model Pembelajaran. Kuningan: Kata Pena.

Nurhadi. (2004). Kurikulum 2004 Pertanyaan dan Jawaban. Jakarta: Grasindo.

Purwatiningsi, S. (2013). Penerapan Model Pembelajaran Penemuan Terbimbing Untuk Meningkatkan Hasil Belajar Siswa Pada Materi Luas Permukaan dan Volume Balok. Jurnal Elektronik Pendidikan Matematiak Tadulako.

Ramadhani, Rini. (2013). Skripsi: Pengaruh Model Problem Based Instruction (PBI) dalam Meningkatkan Kemampuan Pemecahana Masalah Siswa Pada Materi Pokok Aritmatika Sosial Kelas VII SMP Swasta Ampera Batang Kuis T.A 2012/2013. Medan: UNIMED.

Sudjana, Nana. (2009). Penilaian Hasil Proses Belajar Matematika. Bandung: Remaja Rosdakarya. 